\title{
大規模複合再開発施設の利用実態と評価構造に関する研究 東京都23区内10施設を対象として

\author{
STUDY ON ACTUAL USAGE AND EVALUATION STRUCTURE OF \\ LARGE COMPLEX REDEVELOPED BUILDING
} \\ Focusing on 10 facilities in 23 wards in Tokyo
}

\author{
北崎朋希*
}

\section{Tomoki KITAZAKI}

\begin{abstract}
This study's purpose is to clarify the actual usage of large complex redeveloped building used by various people and evaluation structure. Within 10 large complex redeveloped buildings in Tokyo, Marunouchi-area, Roppongi Hills, and Tokyo Midtown have gained a higher level of total satisfaction than other buildings, and the users stay longer and spend more. As a result of analysis of user's evaluation structure, all users consider that "variety" and "topicality" of the large complex redeveloped buildings are important. For this reason, when preparing business plans for large complex redevelopment buildings, it is necessary to give the utmost importance to the aspect of ensuring the variety of tenant shops and facilities and the topicality such as renewals and events, rather than relying on conditions regarding the site and location.
\end{abstract}

Keywords : visitor, worker, resident, visit duration, expenditure, degree of satisfaction 来街者, 就業者, 居住者, 滞在時間, 消費金額, 満足度

\section{1. 本研究の背景と目的}

東京都 23 区における大規模再開発事業注 1 1) は、バブル経済崩壊の 影響を受けて 1990 年代後半に一旦減少したが、2000 年以降再び増 加傾向に転じている。(図 1 参照) これは、バブル経済崩壊後の継続 的な地価下落に伴って事業会社による金融資産としての土地保有意 向が低下したこと、高度経済成長期の初頭に竣工した建築物の建替 時期が到来していること、2002 年に創設された都市再生特別措置法 による大幅な規制緩和などが要因として指摘されている 1)2)。

大規模再開発事業では、様々な用途の施設を組み合わせることが 多い。これは、用途によってリスクとリターンの特性が大きく異な るため、複数の用途を組み合わせることで事業全体のリスクを最小 化し、リターンを最大化させることを目的としている ${ }^{3)}$ 。その結果、 大規模再開発事業によって整備される施設 (以下、「大規模複合再開 発施設」とする。）では、業務、買物・飲食、文化・芸術鑑賞、居住 等の様々な目的を持った人々が利用している。そのため、大規模複 合再開発施設の魅力を長期的に維持するためには、事務所や住宅と いった特定者の利用寸る施設だけではなく、店舗、宿泊施設、文化・ 芸術施設等の不特定者の利用寸る施設がどのように利用され、評価 されているのかを把握することが非常に重要となる。
大規模複合再開発施設の評価を取り扱った研究には、来街者によ る評価を扱った研究 5)、入居者による評価を扱った研究 ${ }^{6)}$ 、地権者 による評価を扱った研究 7)が存在する。これらの研究では、大規模 複合再開発施設の一部の利用主体による評価を対象としており、多 様な利用主体の利用実態や評価を取り扱った研究はない。

そこで本研究では、来街者、就業者、居住者といった利用主体別 に大規模複合再開発施設の利用実態を明らかにし、各施設の満足度 から施設の評価構造を抽出することで、今後の大規模複合再開発施 設の事業計画立案に関する示唆を得ることを目的とする。

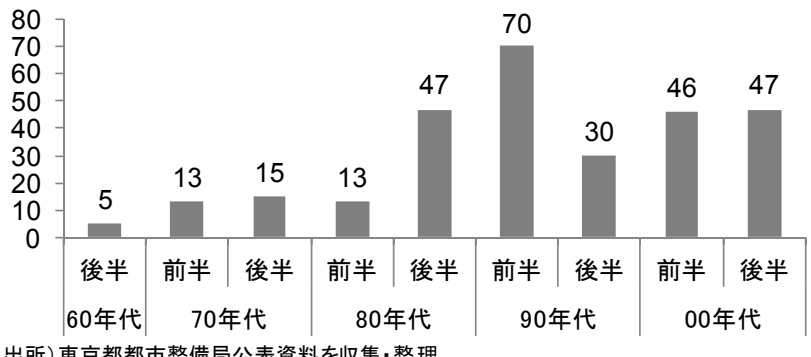

図 1 東京都 23 区における大規模再開発事業件数の推移 


\section{2. 本研究の手法}

本研究では、利用主体別に大規模複合再開発施設の利用実態と満 足度を把握するため、過去 1 年間のうち施設に訪れたことのある者

(来街者：約 5,000 名)、施設内の事務所に勤務している者（就業 者: 約 1,000 名)、施設内の住宅又は施設から徒歩 5 分以内に住ん でいる者（居住者：約 1,000名）に対してインターネットを用いた アンケート調查（2012 年 4 月に実施）を実施した注2)。

アンケート調査では、来街者の居住地の偏りを防ぐため、東京圏 を 10 区分（東京都心、東京副都心、東京城東、東京城南、東京城 西、東京城北、多摩、神奈川県、埼玉県、千葉県の 10 区分）に分 類し、各区分から約 500 名抽出した注 ${ }^{3)}$ 。同様に就業者と居住者の 利用施設の偏りを防ぐため、調查対象とした 10 施設ごとに約 100 名抽出した注 4)。さらに回答者属性の偏りを防ぐため、性別、年齢 (10 歳代、20 歳代、30 歳代、40 歳代、50 歳代、60 歳以上の 6 区分)、 職業（会社員、パート・アルバイト、学生、主婦、無職・その他の 5 区分）の内訳が均等となるように割付した。

アンケート調查で対象とした大規模複合再開発施設は、図 1 で抽 出した事業のうち「(1)事務所、店舗、住宅、宿泊施設等の複数用途 から構成される施設、(2)敷地面積が $2 \mathrm{ha}$ 以上（一体的な計画の下で 開発された施設は同一施設として集計)、(3)施設開業後 1 年以上経 過」に該当した 10 施設を抽出した。抽出した大規模複合再開発施 設は、「(1)丸の内エリア、(2)日本橋室町エリア、(3)晴海トリトンスク エア、(4)六本木ヒルズ、(5)東京ミッドタウン、(6)恵比寿ガーデンプ レイス、(7)汐留シオサイト、(8)大崎エリア、(9)品川エリア、(10天王 洲アイル」である注5)。(表 1 参照）

アンケート調査は、回答者属性、訪問経験、利用実態、施設の満 足度を把握した注 6 )。(表 2 参照)

\section{3. 大規模複合再開発施設の利用実態}

\section{（1） 来街者の利用実態}

(1)訪問経験（図 2 参照)

アンケート調查によると各施設の訪問経験（訪問の有無）は、丸の 内エリアが最も多く、全回答者のうち $59 \%$ は訪問経験を有しており、
表 2 アンケートの質問項目

\begin{tabular}{|c|c|}
\hline 大分類 & 小分類 \\
\hline 回答者属性 & 性別、年齢、職業、居住地、世帯所得 \\
\hline 訪問経験 & 訪問の有無（来街者のみ）、訪問頻度（来街者のみ） \\
\hline 利用実態 & 訪問目的（来街者のみ)、滞在時間、消費金額 \\
\hline 施設の & 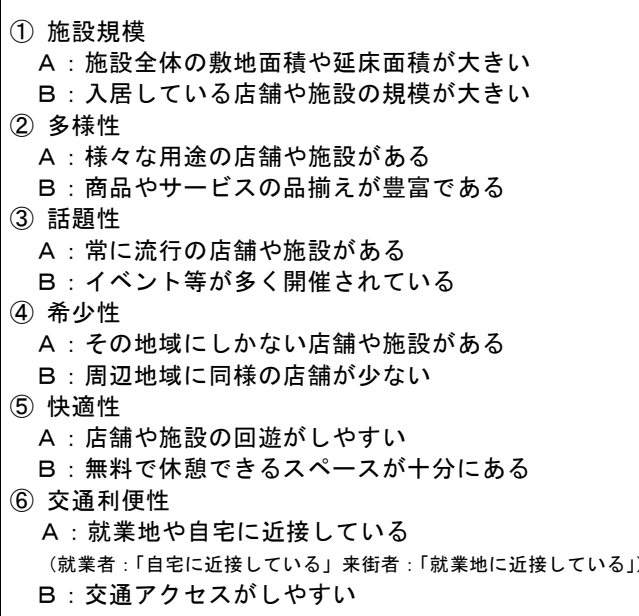 \\
\hline その他 & 大規模複合再開発において必要な公共サービス \\
\hline
\end{tabular}

次いで六本木ヒルズが $56 \%$ 、東京ミッドタウンが $47 \%$ であった。 来街者の居住地をみると、丸の内エリアは東京都心や東京副都心、 さらには東京城東、東京城北、千葉県といった広範囲に居住する者 の訪問経験が高いのに対して、六本木ヒルズや東京ミッドタウンは、 東京都心や東京副都心に加えて東京城南や東京城西といった近隣に 居住する者の訪問経験が高い。これは、丸の内エリアが 6 駅 16 路 線利用可能な交通利便性の高い地域であるからと考えられる。 (2)訪問頻度（図 3 参照)

各施設の訪問頻度は、何れの施設においても年 1 回の頻度で訪問 する割合が最も多く、次いで半年 1 回の頻度で訪問する割合が多い。 しかし、丸の内エリア、品川エリア、大崎エリア等の JR 山手線沿 線の駅に隣接している施設では、3 3 月に 1 回以上の頻度で訪問す る割合が高い特徴がある。

表 1 調查対象の大規模複合再開発施設の概況注 7)

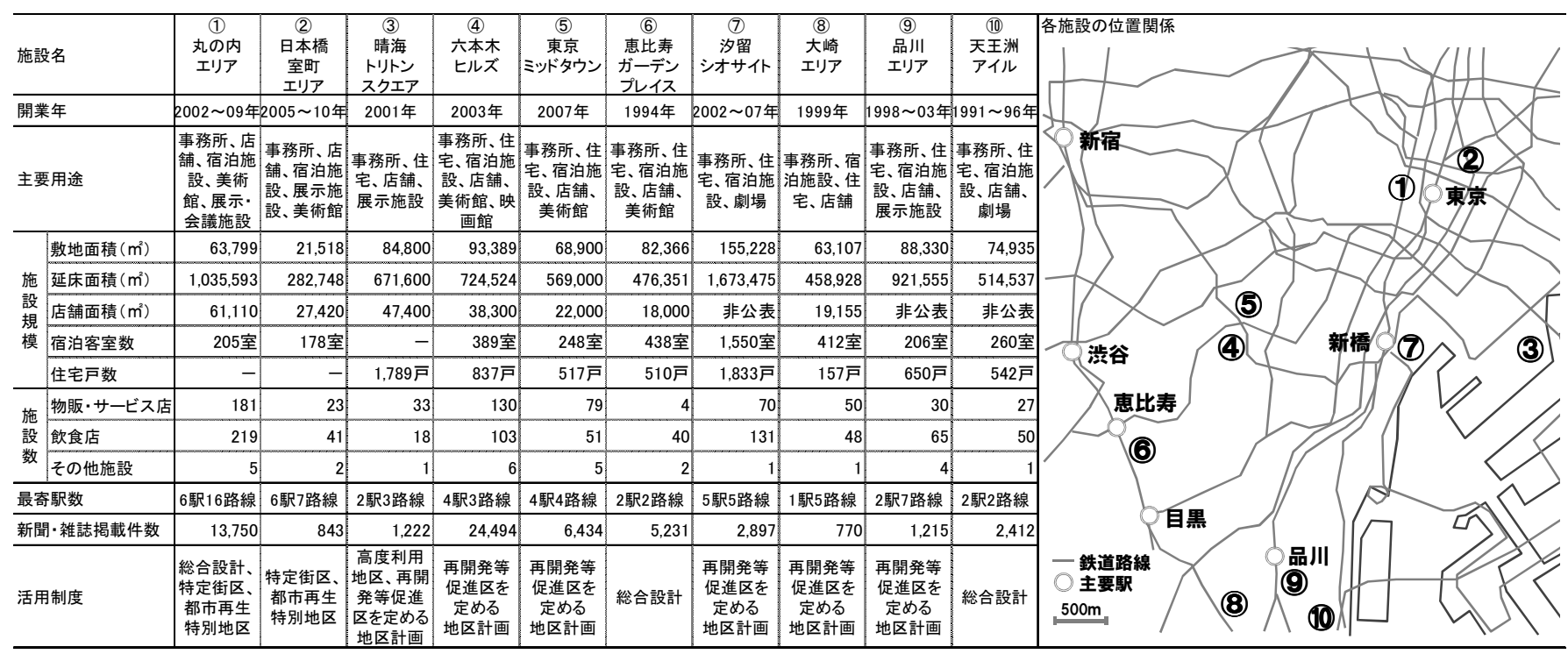




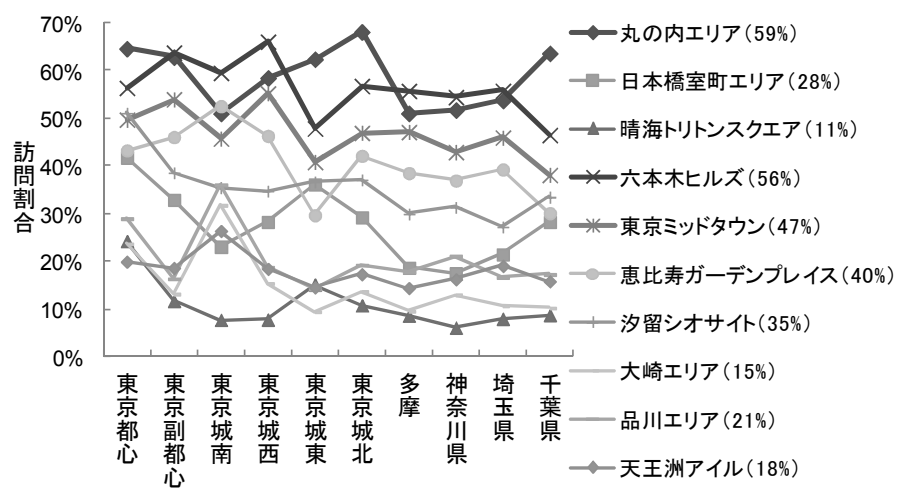

図 2 来街者注 8)の居住地別訪問経験（括弧内は総数に対する訪問割合） $\begin{array}{llllll}0 & 20 \% & 40 \% & 60 \% & 80 \% & 100 \%\end{array}$

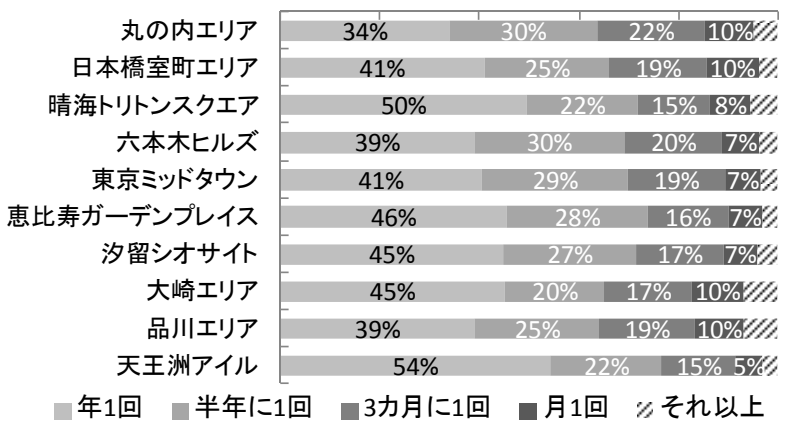

図 3 来街者の訪問頻度 $(\mathrm{n}=5,303)$

$0 \% \quad 20 \% \quad 40 \% \quad 60 \% \quad 80 \% \quad 100 \%$

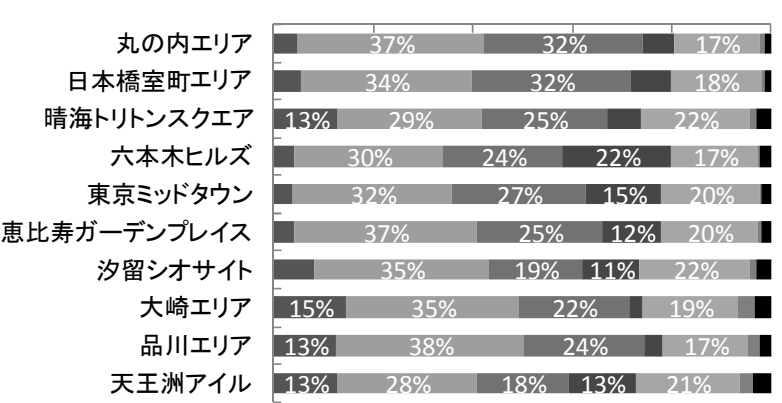

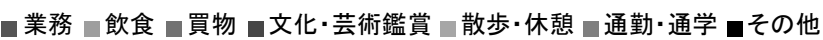

図 4 来街者の訪問目的（単一回答、 $\mathrm{n}=5,303$ )

\section{(3)訪問目的（図 4 参照）}

各施設の訪問目的は、何れの施設においても飲食目的が最も多く、 次いで買物目的、散歩・休数目的となっている。特に丸の内エリア や日本橋室町エリアは、買物目的の割合が高い傾向にある。

一方、六本木ヒルズや東京ミッドタウンでは、文化・芸術鑑賞目 的も比較的高い傾向にある。これは、上記施設が他施設と比較して、 劇場、美術館、映画館などのその他施設が多数入居していているか らと考えられる。

(4)滞在時間（図 5 参照）

各施設の滞在時間は、六本木ヒルズが約 2.8 時間と最も長く、次 いで東京ミッドタウンの約 2.5 時間、丸の内エリア、恵比寿ガーデ ンプレイス、汐留シオサイトの約 2.4 時間となっている。

滞在時間の内訳をみると、平均滞在時間の短い日本橋室町エリア、 晴海トリトンスクエア、大崎エリア、品川エリアでは来街者の約 7 割が 3 時間未満で占められているのに対して、平均滞在時間の長い 六本木ヒルズ、東京ミッドタウンでは来街者の約 4 割が 3 時間以上

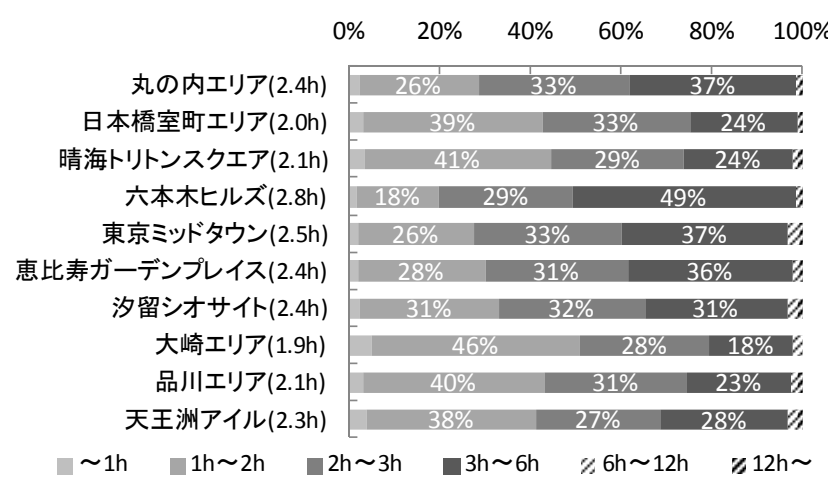

図 5 来街者の滞在時間内訳（括弧内は平均滞在時間、 $\mathrm{n}=5,303$ ) $\begin{array}{llllll}0 \% & 20 \% & 40 \% & 60 \% & 80 \% & 100 \%\end{array}$

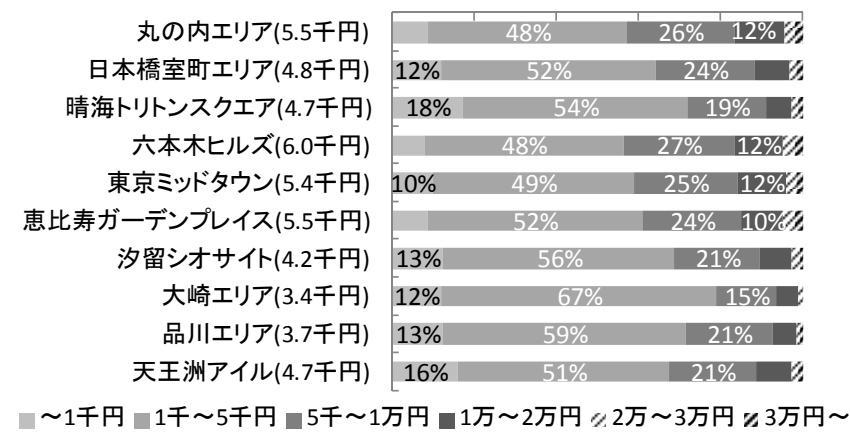

図 6 来街者の消費金額内訳（括弧内は平均消費金額、 $\mathrm{n}=5,303$ ) $\begin{array}{lllll}0 \% & 20 \% & 40 \% & 60 \% & 80 \%\end{array}$

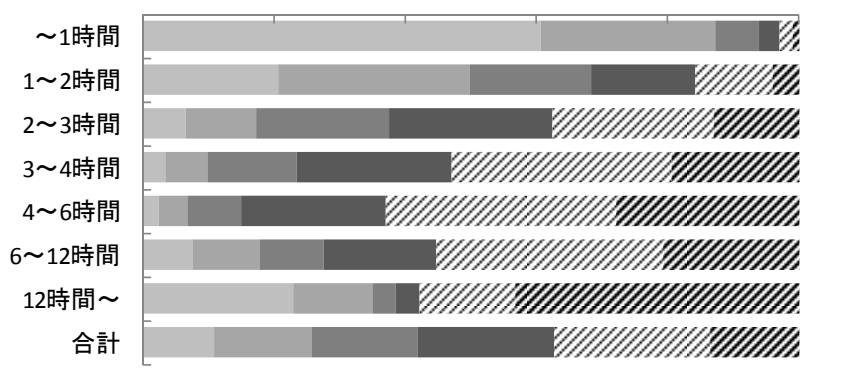

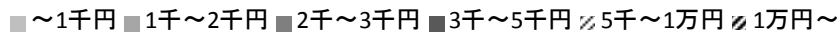

図 7 滞在時間別の消費金額内訳注 9) $\quad(n=5,303)$

で占められている。

(5)消費金額（図 6 参照）

各施設の消費金額は、六本木ヒルズが約 6,000 円と最も高く、次 いで丸の内エリアと恵比寿ガーデンプレイスの約 5,500 円、東京ミ ッドタウンの約 5,400 円となっている。

消費金額の内訳をみると、晴海トリトンスクエア、大崎エリア、 品川エリアでは来街者の約 7 割が 5,000 円未満で占められているの に対して、六本木ヒルズ、丸の内エリア、東京ミッドタウンでは来 街者の約 4 割が 5,000 円以上で占められている。

6)滞在時間別の消費金額（図 7 参照）

滞在時間別の消費金額の内訳をみると、滞在時間が長くなるほど 消費金額の高い割合は増加する傾向にある。特に滞在時間が 1 時間 未満と $1 \sim 2$ 時間、6〜 12 時間と 12 時間以上の消費金額の内訳には 大きな差が存在する。これは、1 時間未満の来街者には全く消費を しない来街者が多く存在すること、12 時間以上の来街者は宿泊を伴 っていることが要因と考えられる。 


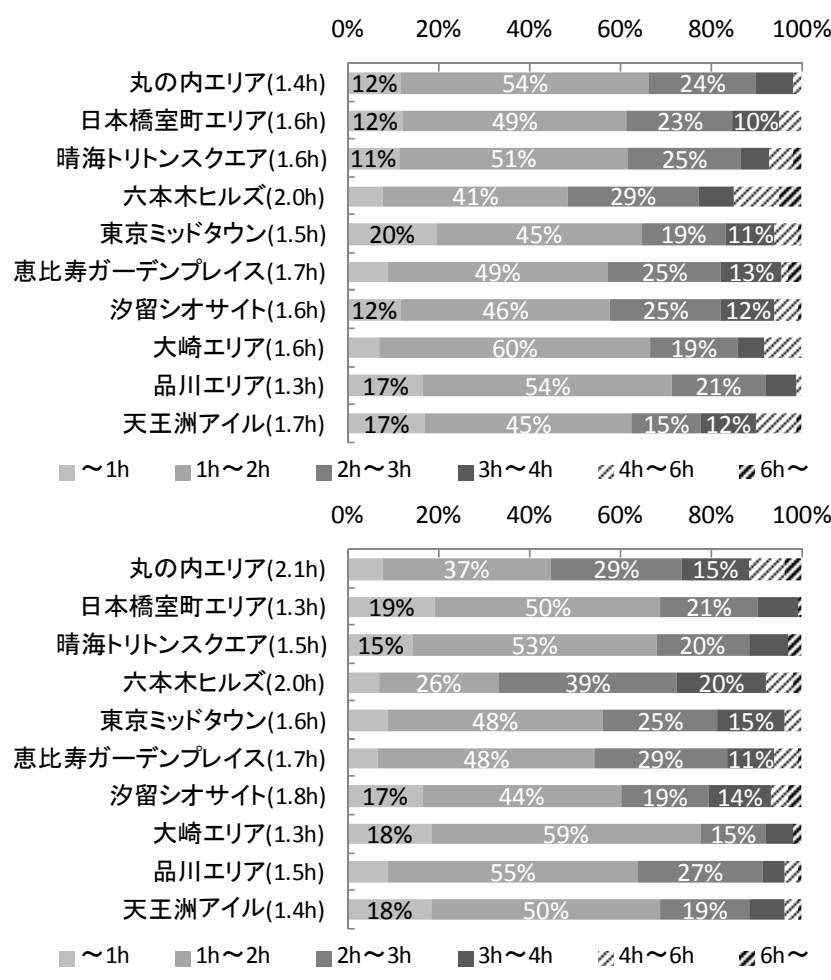

図 8 各施設の滞在時間内訳（上：就業者注 10$) 、 下 ：$ 居住者注 ${ }^{11}$ )

\section{（2） 就業者、居住者の利用実態}

(1)滞在時間（図 8 参照）

就業者の滞在時間をみると、最も平均滞在時間の長い施設は六本 木ヒルズの約 2.0 時間であり、次いで恵比寿ガーデンプレイスと天 王洲アイルの約 1.7 時間となっており、総じて来街者よりも滞在時 間は短い傾向にある。一方、居住者の滞在時間をみると、最も平均 滞在時間の長い施設は丸の内エリアの約 2.1 時間であり、次いで六 本木ヒルズの約 2.0 時間、汐留シオサイトの約 1.8 時間となってお り、平均滞在時間は就業者と同程度である。就業者と居住者の滞在 時間の内訳をみると、何れの施設においても 1 2 時間が最も多く、 次いで $2 \sim 3$ 時間、 1 時間未満が多い傾向にある。

(2)消費金額（図 9 参照）

就業者の消費金額をみると、最も平均消費金額の高い施設は六本 木ヒルズの約 1,700 円であり、次いで丸の内エリアと日本橋室町エ リアの約 1,600 円となっており、全ての施設において来街者よりも 消費金額は低い傾向にある。一方、居住者の消費金額をみると、最 も平均消費金額の高い施設は六本木ヒルズの約 7,200 円であり、次 いで丸の内エリアの約 6,100 円、恵比寿ガーデンプレイスの約 5,600 円となっており、丸の内エリア、六本木ヒルズ、恵比寿ガーデンプ レイス、品川エリアは来街者よりも高い傾向にある。

居住者の消費金額の内訳をみると、全体平均では回答者のうち約 $70 \%$ が 5,000 円未満であるが、丸の内エリア、六本木ヒルズ、東京 ミッドタウン、恵比寿ガーデンプレイス、汐留シオサイトは 5,000 円未満が約 $60 \%$ と低く、約 $40 \%$ 以上が 5,000 円以上で占められて いる。 $\begin{array}{llllll}0 \% & 20 \% & 40 \% & 60 \% & 80 \% & 100 \%\end{array}$

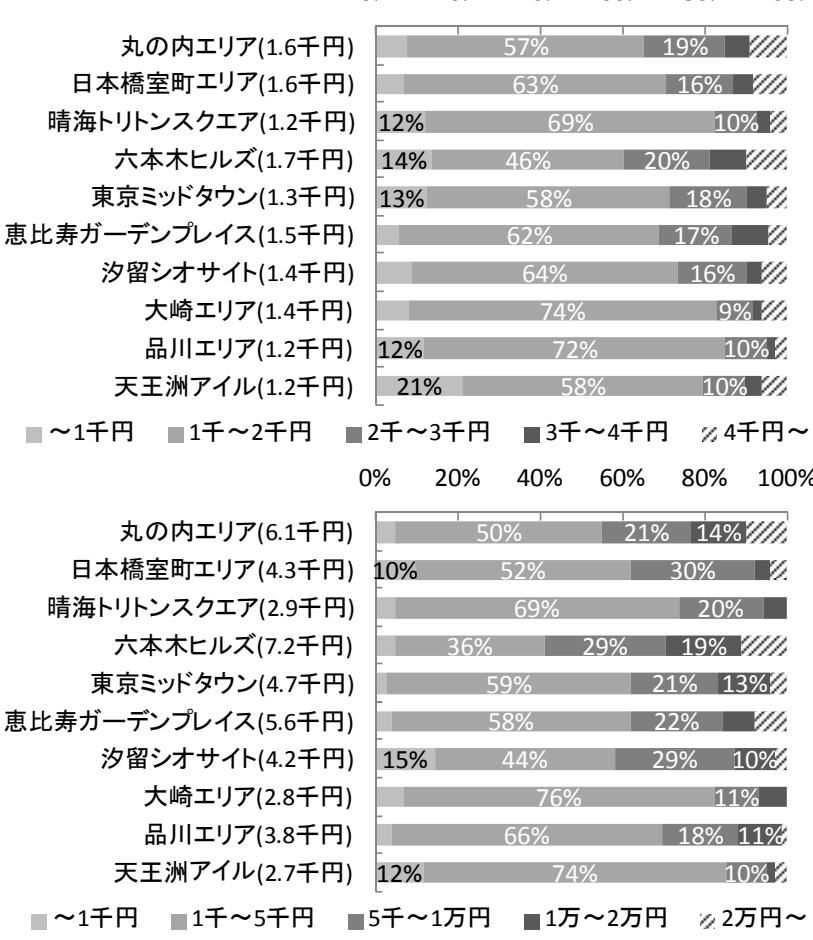

図 9 各施設の消費金額内訳（上: 就業者、下: 居住者)

\section{4. 大規模複合再開発施設の評価 \\ (1) 各施設の満足度}

大規模複合再開発施設の満足度を評価するため、各利用主体に施 設の総合満足度を 10 点満点で回答して頂いた。その結果、来街者 及び就業者では丸の内エリアが最も高く、次いで六本木ヒルズ、東 京ミッドタウンとなった。また居住者では東京ミッドタウンが最も 高く、次いで丸の内エリア、六本木ヒルズ、恵比寿ガーデンプレイ スとなった。(図 10 参照)

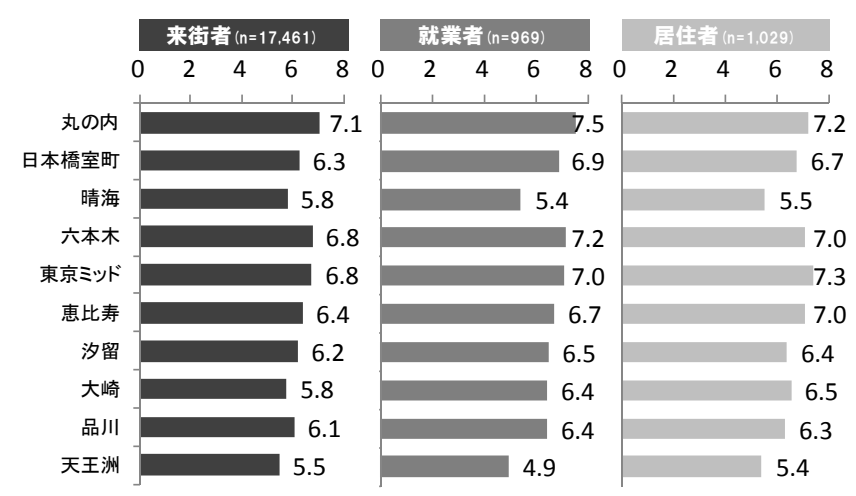

図 10 大規模複合再開発施設の総合満足度

次に各施設における 6 分野 12 項目（表 2 参照）から構成される 評価要素の個別の満足度を把握するため、各要素を 5 段階評価「不 満 (1 点)、やや不満（2 点）、どちらともいえない（3 点）、やや満 足 (4 点)、満足 (5 点)」によって点数化した。(図 11 参照) この 結果をみると、総合満足度の高い丸の内エリア、六本木ヒルズ、東 京ミッドタウンは他施設と比較して、施設規模、多様性、話題性 A （常に流行の店舗や施設がある）の要素において高い評価を得て 

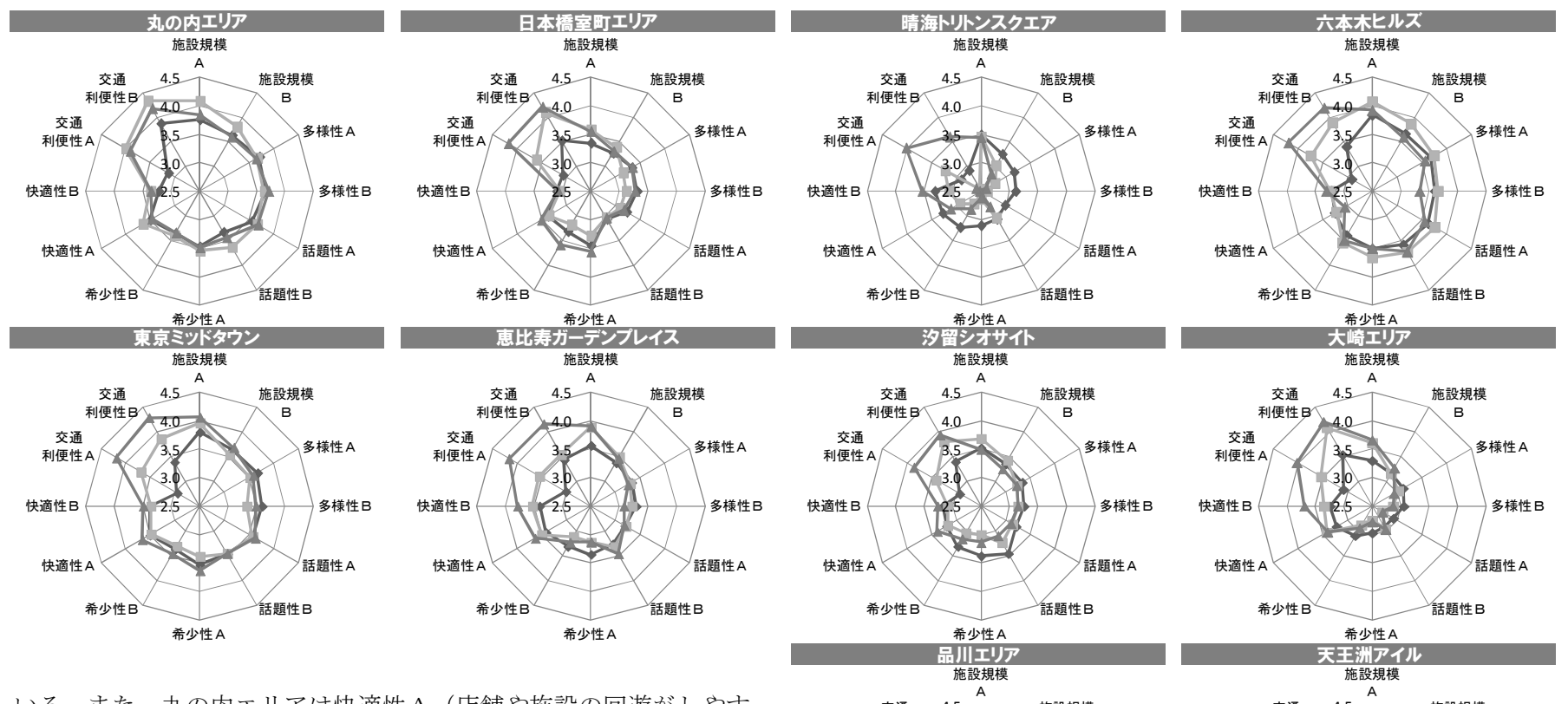

いる。また、丸の内エリアは快適性 A（店舗や施設の回遊がしやす い) や交通利便性 B (交通アクセスがしやすい)、六本木ヒルズは話 題性B（イベント等が多く開催されている）、東京ミッドタウンは快 適性 B（無料で休顋できるスペースが十分にある）といった項目に おいて高い評価を得ている。こうした高い評価が丸の内エリアの高 い訪問経験、六本木ヒルズや東京ミッドタウンの幅広い訪問目的に 影響を与えていると考えられる。

\section{(2) 施設の総合満足度と滞在時間及び消費金額の関係}

来街者における総合満足度別の滞在時間及び消費金額の内訳をみ ると、総合満足度が高くなるほど滞在時間の長い来街者や消費金額 の高い来街者の割合が増加する傾向にある。このことが総合満足度 の高い丸の内エリア、六本木ヒルズ、東京ミッドタウンの滞在時間 の長さや消費金額の高さに起因しているものと考えられる。
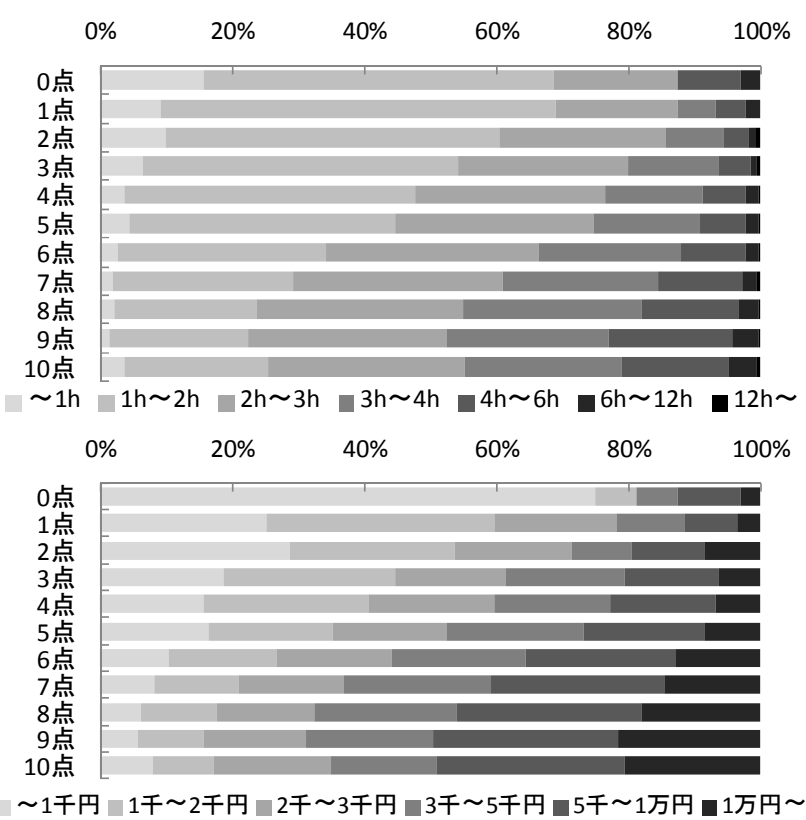

図 12 総合満足度別の滞在時間（上）及び消費金額（下）の内訳
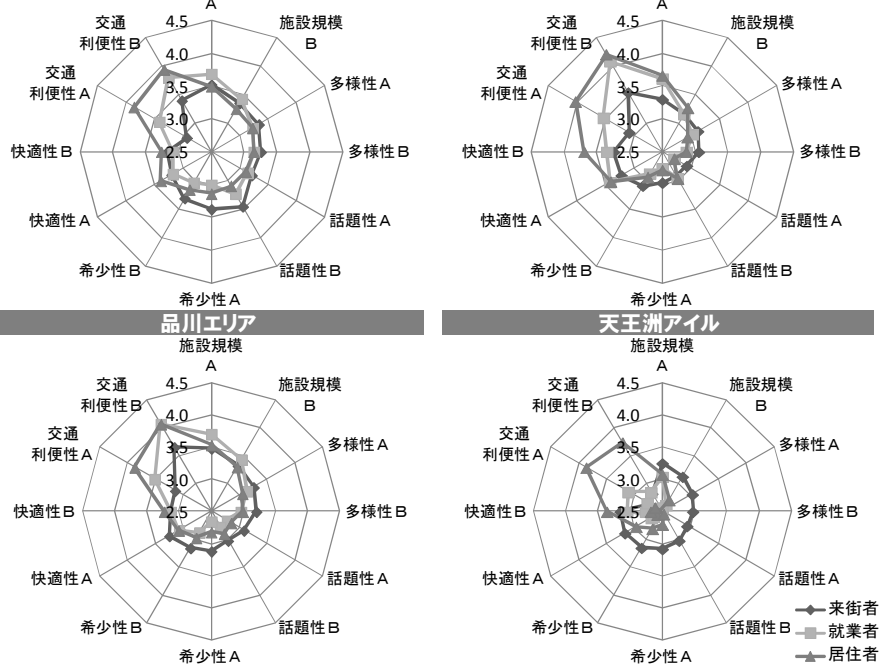

図 11 利用主体別の各施設における個別満足度

\section{（3） 大規模再開発施設に必要な公共サービスの把握}

大規模複合再開発施設では、周辺に与える影響が大きいため、事 業者の負担によって様々な公共サービスが提供されている。これら の公共サービスの評価を把握するため、5 分野 16 項目から構成され る公共サービス注 12) を 4 段階評価「必要ではない（1 点）、どちらか というと必要である (2 点)、必要である（3 点）、とても必要であ る (4 点)」によって点数化した。(図 13 参照)

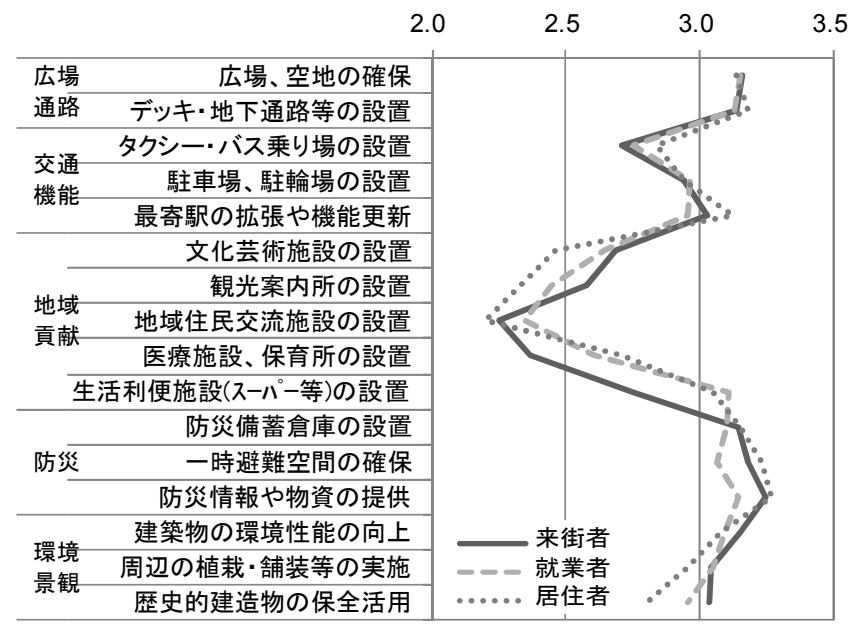

図 13 大規模再開発施設において必要な公共サービスの評価

この結果をみると、「広場・通路、交通機能、防災、環境・景観」 の分野は何れの項目も高い評価を得ているが「地域貢献」は項目に 
よって大きく評価が分かれた。特に利用者が限定される「地域住民 交流施設、医療施設・保育所」は低い評価であった。近年、事業者 から提案された公共サービスを評価して容積率等の規制緩和を認め る都市再生特別地区は増加 $\left.{ }^{8}\right)$ 寸る傾向にあるが、公共サービスの評 価には利用主体の意向のみならず、各施設の充足状況等も勘案する 必要があるといえる。

\section{5. 大規模複合再開発施設の評価構造 (1) 評価構造の構築}

施設における評価構造を抽出して 6 分野 12 項目から構成される 評価要素の重要度を把握するため、6 分野を潜在変数とし、12 項目 を観測変数とした共分散構造分析を実施した。共分散構造分析とは、 類似した傾向を示す多くの観測変数を直接計測することのできない 潜在変数により統合し、変数相互の関連性を計量化する手法であり、 潜在変数間の因果関係を明らかにすることが可能となる。

評価構造に用いるパス図は、大規模複合再開発施設の総合評価に 直接影響を与える 6 つの潜在変数とこれを代表する観測変数を決定 するため「三次因子モデル」とした。これは、潜在変数同士の内部 相関を排除した高次因子モデルにすることによって、潜在変数の総 合評価から各観測変数までのパス係数の積の算出を可能とし、本分 析の目的の一つである観測変数の重要度を定量化することが可能と なる。このモデルでは、6つの潜在変数の上位にある潜在変数を「総 合評価」とし、これと観測変数の「総合満足度」との間には潜在変 数を介さずに直接的な関係があるものと仮定した。

\section{(2) 評価構造の解釈}

図 14 は共分散構造分析を行った結果である。この結果では、各 パス係数の $\mathrm{t}$ 值は全て $1 \%$ 有意水準を満足し、かつモデルの適合度 を表す指標 GFI(Goodness of Fit Index)も来街者は 0.951、就業者 は 0.938、居住者は 0.924 と良好な值を示した。これらの結果から、 パス図は、「利用主体の評価構造モデル」を表現するモデルとして信 頼性が高いと判断した。

この結果をみると、来街者の総合評価に最も影響を与えているの は「話題性」であり、次いで「多様性」「希少性」の順となってい る。また、就業者では「多様性」、話題性」「快適性」、居住者では 「快適性」、「多様性」、「話題性」の順で総合評価に影響を与えてい る。このことから、「多様性」や「話題性」は全ての利用主体の総合 評価において高い影響を与えているといえる。さらに来街者は「希 少性」、就業者や居住者は「快適性」を重視している。これは来街者 と比較して、就業者や居住者は訪問頻度が高いため、より「快適性」 を重視する傾向があると考えられる。一方、「施設規模」や「交通利 便性」は、何れの利用主体においても総合評価に与える影響は低い 傾向にある。

次に全ての利用主体の総合評価に高い影響を与えている「多様性」 や「話題性」を構成する観測変数をみると、「多様性」を構成する 2 つの観測変数「様々な用途の店舗や施設がある、商品やサービスの 品揃えが豊富である」は、何れの利用主体においても高い重要度で ある。一方、「話題性」をみると、来街者は 2 つの観測変数「常に 流行の店舗や施設がある、イベント等が多く開催されている」の重 要度が高いのに対して、就業者や居住者は「常に流行の店舗や施設 がある」のみ高い重要度であった。このことから、「話題性」に関し
ては、来街者と就業者及び居住者で重視する側面が異なるといえる。
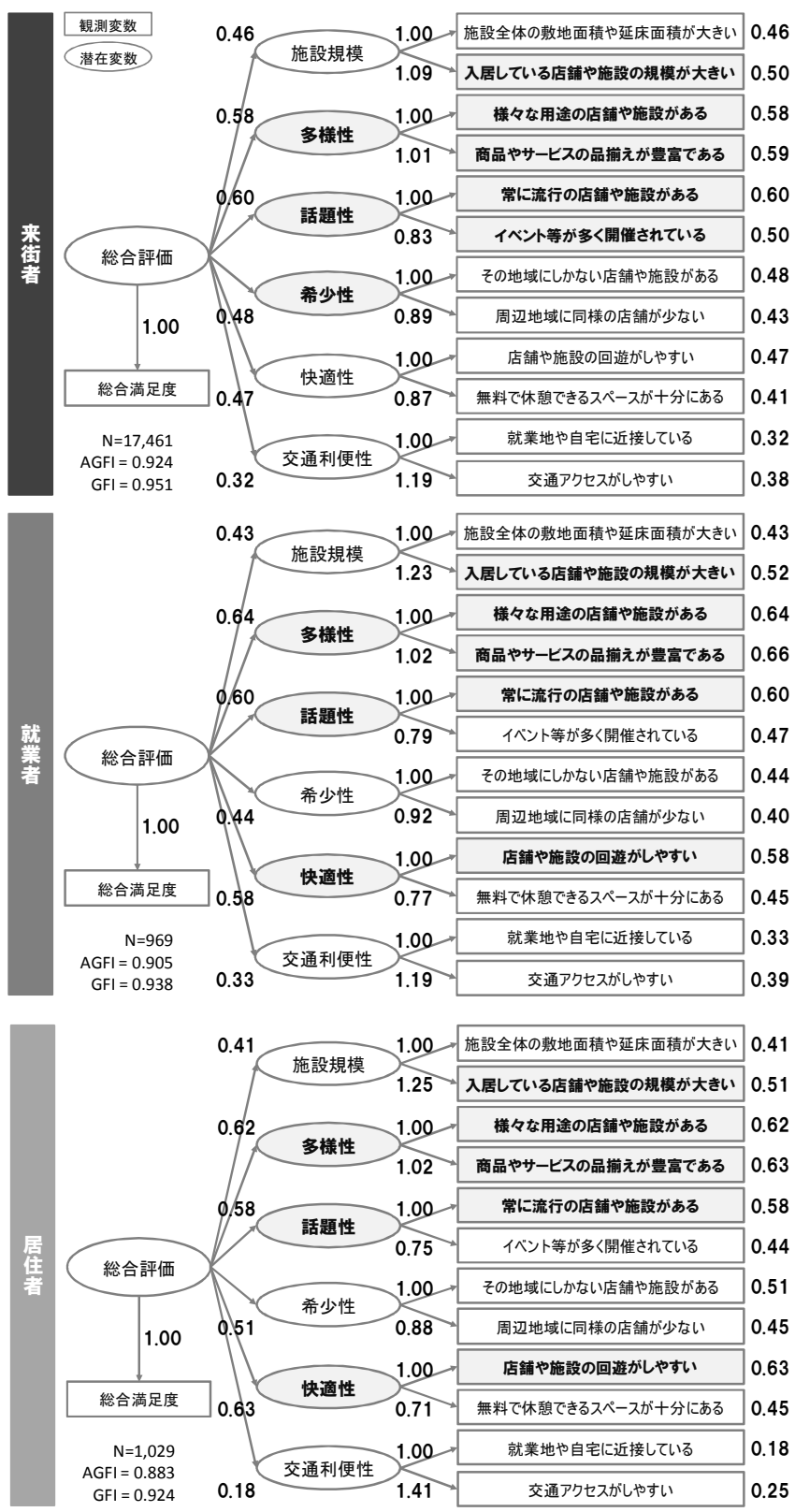

※) 矢印の数值はパス係数を示してお以、12項目の右側数值は総合評価から各観測変数までのパス係数の積で あり、重要度を示している。また、6分野の網掛けはパス係数が上位3指標、12項目の網掛けは重要度が上位 5指標を示している。

\section{図 14 共分散構造分析の結果}

\section{6. 本研究の総括}

本研究では、東京 23 区内に存在する 10 の大規模再開発複合施設 の来街者 5,303 名、就業者 969 名、居住者 1,029 名へのアンケート 調査から、各施設の利用実態及び満足度を把握し、各施設の評価結 果を用いて評価要素の重要度を把握できる評価構造を導出した。

この評価構造をみると、多様な利用主体の総合評価を高めるため には、何れの利用主体も重視している「多様性」と「話題性」を高 める必要があり、そのためには常に人気の高い様々な用途の店舗や 施設を多数配置したり、商品やサービスの品揃えを充実させる必要 がある。さらに来街者を重視する場合には、その地域にしかない店 舗や施設を配置して「希少性」を向上したり、就業者や居住者を重 
視する場合には店舗や施設の回遊性を高めて「快適性」を向上する ことが各利用主体の総合評価を高めるために効果的となる。一方、 大規模再開発事業の所与の条件である施設規模や交通利便性は、全 ての利用主体の総合評価に与える影響は小さく、前述の「多様性、 話題性、希少性、快適性」に十分配慮することで高い総合評価を得 ることが可能である。例えば、東京ミッドタウンや六本木ヒルズは、 来街者からの交通利便性に対する評価は低いにも関わらず、総合評 価は丸の内エリアに次いで高い評価を得ている。これは、東京ミッ ドタウンや六本木ヒルズの多様性や話題性が高く評価されているこ とに要因がある。また恵比寿ガーデンプレイスは、総合評価の上位 3 施設と比較して、開業が 10 年以上も古いにも関わらず、各利用主 体の総合評価は上位 5 施設に位置付けられている。これは、飲食店 を中心とした継続的なリニューアルやイベントの開催等により、多 様性と話題性の評価を維持していることが影響していると考えられ る。その証拠として、恵比寿ガーデンプレイスの新聞・雑誌掲載件 数は同時期に開業した天王洲アイルよりも大きく上回っている。

このように大規模再開発事業の事業計画策定時には、敷地条件や 立地条件に依存するのではなく、入居する店舗や施設に加えて商品 やサービスの多様性、リニューアルやイベント開催等の話題性、周 辺地域や類似施設との差別化を通した希少性の確保といった観点を 最も重視する必要があるといえる。また、これらの評価要素は時間 と共に変化するため、継続的に満足度を高めるためにも常にモニタ リングし、施設運営を改善していくことが必要であると考える。

\section{参考文献}

1）松原宏:グローバル経済・人口減少社会における日本の都市システムと 都市内部構造の再編, 経済地理学年報 53 巻 5 号, pp. 443-460, 2007. 12

2) 矢部直人:不動産証券投資をめぐるグローバルマネーフローと東京にお ける不動産開発, 経済地理学年報 54 巻 4 号, pp. 292-309, 2008. 12

3) 岡崎剛, 中井検裕: リスク・リターンから見た都心部開発における最有効 用途構成に関する研究, 日本不動産学会誌 Vol. 18No. 1, pp49-57, 2004

4）鈴木聡士:センシャス・ポテンシャルモデルによる中心市街地再開発事 業の評価に関する研究, 日本都市計画学会学術研究発表会論文集 No35, pp. 163-168, 2000. 10

5）宮地淳貴, 河野朗:市民から見た再開発の評価手法に関する研究 $-U$ 市に おける取り組みを事例として一, 再開発研究 No18, pp51-59, 2002

6) 安藤元夫: 新長田駅南地区復興再開発ビル入居店舗経営者の意識調査に よる事業評価に関する研究, 日本都市計画学会学術研究発表会論文集 No40-3, pp157-162, 2005. 10

7）石丸紀興, 沈振江: 広島市段原地区再開発事業における住民の事後評価 の類型に関する研究: その 1 旧地主持ち家層の場合, 日本建築学会計画 系論文集 No. 500，pp177-184，1997. 10

8）北崎朋希: 都市再生特別地区における公共貢献と規制緩和の実態と課題 一東京都における都市再生特別地区を対象として一, 日本都市計画学会学 術研究発表会論文集 No46-3，pp583-588，2011. 10

注

注1）再開発事業では、事業収益を最大化させるため、既存の都市計画による 規制（用途地域、容積率、建蔽率、斜線制限等）の緩和を行うことが一 般的である。そのため、本研究では東京都において既存の都市計画によ る規制の緩和手法として多く用いられる都市開発諸制度（特定街区、高 度利用地区、再開発等促進区を定める地区計画、総合設計) 及び都市再 生特別地区を活用した事業で指定面積が 1.0 ha 以上の事業を大規模再 開発事業と定義した。

注2）アンケート調査では、来街者は訪問経験のある全ての施設、就業者及び 居住者は自らが就業又は居住している施設のみの回答を個人票として 得た。なお居住者は回答数を確保することが困難であることを想定した ため、施設内外の割付は行っていない。

注3）各地域の回答者数は、東京都心 511 名、東京副都心 532 名、東京城東
516 名、東京城南 527 名、東京城西 529 名、東京城北 520 名、多摩 555 名、神奈川県 540 名、埼玉県 540 名、千葉県 538 名の計 5,303 名である。 来街者の標本数の算出には、10 施設のうちで総利用者数が最大の六本 木ヒルズ（六本木 6 丁目）の約 4, 100 万人（森ビル(株プレスリリース、 2013 年 4 月 24 日) 在参考に総利用者数からエリア内の就業者数 18,468 人 (平成 21 年経済センサス基礎調査) と居住者数 1,597 人（平成 22 年 国勢調査) に年間労働日数 247 日と年間日数 365 日を乗じた值を差し引 いた 3, 586 万人を母数とした。この母数において信頼区間 $95 \%$ ・許容誤 差 $10 \%$ に必要な標本数は 96 名であったが、来街者は属性別にクロス集 計を行うことを想定したため、各施設の標本数が 500 名以上となるまで 各地域の回答数を得た。

注4）就業者と居住者の標本数の算出には、10 施設のうちで施設規模が最大 の汐留シオサイト（東新橋 $1 \sim 2$ 丁目）の就業者数 66,934 人 (平成 21 年経済センサス基礎調査）と居住者数 7,017 人（平成 22 年国勢調査、 周辺の銀座 8 丁目、新橋 $1 \sim 6$ 丁目、浜松町 1 丁目、海岸 1 丁目を含む) を母数とした。この母数において信頼区間 $95 \%$ ・許容誤差 $10 \%$ に必要な 標本数は 95 名であることから 100 名をアンケート調査の標本数とした。

注5）各エリアの対象施設は、丸の内エリア（丸ビル、新丸ビル、丸の内オア ゾ、東京ビル（TOKIA）、丸の内ブリックスクェア）、日本橋室町エリ ア (日本橋三井タワー、コレド室町、ユイト日本橋室町ビル)、大崎エ リア（大崎ニューシティ、ゲートシティ大崎）、品川エリア（品川イン ターシティ、品川グランドコモンズ）である。

注6）就業者及び居住者の訪問頻度及び訪問目的は施設間に大きな差異がみ られないと判断したため、質問項目から除外した。また質問項目のうち 訪問経験は来街者のみに実施し、就業者の滞在時間は就業時間を除いた 時間、居住者の滞在時間は在宅時間を除いた時間を把握した。

注7）表中の施設概況は 2012 年 4 月時点の状況であり、各施設のホームペー ジ及び施設運営会社へのヒアリングを基に作成した。また、新聞・雑誌 掲載件数は、各施設の開業時期から 2012 年 4 月末までに侏日本経済新 聞デジタルメディアが提供する国内最大級のデータベースである日経 テレコンで検索可能な 54 の新聞と 149 の雑誌に掲載された件数を集計 したものである。

注8）来街者における各施設の回答数は、丸の内エリア 3,111 名、日本橋室町 エリア 1, 464 名、晴海トリトンスクエア 573 名、六本木ヒルズ 2, 981 名、 東京ミッドタウン 2,471 名、恵比寿ガーデンプレイス 2,142 名、汐留シ オサイト 1, 880 名、大崎エリア 793 名、品川エリア 1, 090 名、天王洲ア イル 956 名である。

注9）各滞在時閒帯の回答数は 1 時間未満 393 名、 1 時間以上 2 時間未満 5,157 名 2 時間以上 3 時間未満 5, 476 名、3 時間以上 4 時間未満 3, 865 名、4 時間以上 6 時間未満 2, 067 名、 6 時間以上 12 時間未満 420 名、12 時間 以上 83 名である。

注10)各施設の就業者における回答数は、丸の内エリア 101 名、日本橋室町エ リア 99 名、晴海トリトンスクエア 97 名、六本木ヒルズ 101 名、東京ミ ッドタウン 102 名、恵比寿ガーデンプレイス 68 名、汐留シオサイト 102 名、大崎エリア 99 名、品川エリア 101 名、天王洲アイル 99 名の計 969 名である。

注11) 各施設の居住者における回答数は、丸の内エリア 103 名、日本橋室町エ リア 103 名、晴海トリトンスクエア 103 名、六本木ヒルズ 102 名、東京 ミッドタウン 103 名、恵比寿ガーデンプレイス 103 名、汐留シオサイト 103 名、大崎エリア 103 名、品川エリア 103 名、天王洲アイル 103 名の 計 1,029 名である。

注12)公共サービスの項目は、都市再生特別地区を活用した事業における公共 貢献を網羅的に整理している参考文献 8）を基に設定した。

（2013年 4 月 1 日原稿受理，2013年10月 3 日採用決定） 